\title{
Evidence-Seeking as an Expression of Faith
}

\author{
Katherine Dormandy \\ [forthcoming in The American Catholic Philosophical Quarterly]
}

\begin{abstract}
Faith is often regarded as having a fraught relationship with evidence. Lara Buchak even argues that it entails foregoing evidence, at least when this evidence would influence your decision to act on the proposition in which you have faith. I present a counterexample inspired by the book of Job, in which seeking evidence for the sake of deciding whether to worship God is not only compatible with faith, but is in fact an expression of great faith. One might still think that foregoing evidence may make faith more praiseworthy than otherwise. But I argue against this claim too, once more drawing on Job. A faith that expresses itself by a search for evidence can be more praiseworthy than a faith that sits passively in the face of epistemic adversity.
\end{abstract}

\section{Introduction}

Faith is often regarded as having a fraught relationship with evidence. The intuition is even strong in some circles that it entails foregoing evidence. My aim here is to argue that this intuition is mistaken. Not only does faith not entail foregoing evidence, the search for evidence can be an expression of great faith.

To make this argument I engage with Lara Buchak's recent account of faith (section 2), according to which a person has faith that a proposition is true only if she declines to seek additional evidence concerning its truth, at least for the purpose of practical reasoning Buchak, 2012, Buchak, 2014. Buchak's account is of particular interest because it is more congenial to evidentialist sympathies than are other views that link faith with foregoing evidence. For on her account, the faithful person can start off with as much evidence as she pleases, stopping short only of full certainty. All that Buchak says is that, in order to count as having faith, she must decline to seek any more.

This view is intuitively plausible across a wide range of cases. If before lending me money you opt to investigate whether I have repaid past loans, you do not seem to have faith that I will repay you. That doubting Thomas refused to believe that Jesus was resurrected in the flesh until he put his hand in Jesus' side does seem to indicate a lack of faith that Jesus was resurrected in the flesh. And so forth.

Yet I will argue (section 3) that Buchak's account is mistaken: you can have faith without declining to seek evidence. Her account may pinpoint a regularity that applies across many cases of faith, but it falls short of being a necessary condition 1 My argument takes the form

\footnotetext{
${ }^{1}$ I argue elsewhere that Buchak's account does not provide a sufficient condition either [reference omitted].
} 
of a counterexample that elaborates on the story of Job. I argue for the (perhaps initially counterintuitive) claim that searching for evidence for the sake of practical reasoning can in the right circumstances constitute an act of faith.

One might still think, however, that even if declining to seek evidence is not necessary for faith, it still makes for a more praiseworthy faith. I argue that this normative claim is false too (section 4). Once more I draw on an example from the book of Job. A particularly laudable form of faith, I argue, combines loyalty with integrity, where the integrity is both moral and epistemic. Seeking evidence for the purpose of practical deliberation can make for a praiseworthy faith. I offer some remarks (section 4.2 to explain the intuitions behind the idea that evidence-seeking is either incompatible with faith or at least makes faith less praiseworthy.

\section{Faith as Declining to Seek Evidence}

Buchak's main account is of propositional faith, that is, faith that $p$. I will limit the discussion to cases of propositional faith where the proposition in question concerns a person, as in "I have faith that you will keep my secret." |2

Buchak is concerned with the seeking of evidence for the sake of determining how to act, not how to believe. This focus brings out an important aspect of faith: our actions are arguably a better gauge of our deepest commitments than our beliefs. It is one thing (Buchak notes) to believe that God exists, and another to sell all of one's belongings and give the proceeds to charity.

On Buchak's account, faith that $p$ does not require belief that $p 3^{3}$ Rather, all that it requires is the disposition to act on the truth of $p$, where you would prefer not to act this way if you took $p$ to be false. So your faith that your friend is discrete entails a disposition to tell her an important secret, where you would not want to do so if she were not discrete. Faith dispositions are often (but not necessarily, I take it) the result of a commitment to act as if the faith proposition is true, so if you in fact lose your belief that $p$, keeping your faith might involve acting as if $p$ is true anyway Hence the first of Buchak's five necessary conditions for faith that $p$ (Buchak, 2012], 226-228) is that you are disposed to take $p$ to be true in your practical reasoning. More specifically, you are disposed to perform an action that is an expression of your faith that $p$. If for example I have faith that God answers prayers, I will be disposed to express my faith by praying (where I would be disinclined to pray if I thought he did not exist, though might do so anyway to keep a faith commitment).

The second condition is that it matters to you whether $p$ is true or false. For example, if you tell me something but don't care who else finds out about it, then you don't count as having faith that I am discrete.

\footnotetext{
${ }^{2}$ One might think that the target form of faith should be faith in a person. I am sympathetic, but my aim here is to address Buchak's account.

${ }^{3}$ In this her account parts ways from Plantinga, 2000, Aquinas, 1485/1974, and Locke, 1690/1997; and resembles that of Swinburne, 2005 and Bishop, 2007].

${ }^{4}$ Buchak sometimes writes as if the disposition to act just is a commitment. She does not discuss the implications for a faith in which the disposition is sustained by a commitment as opposed to faith in which there is no commitment.
} 
Third, you have a positive attitude toward the truth of $p$. For example, if you are afraid that the secretary has lost your important documents, then, since fear is a negative attitude toward the proposition that he has lost them, you don't have count as having faith that he has done so 5

Fourth, you are not certain that $p$ is true; that is, its falsehood is compatible with your evidence. For example, if your sister has just ushered you into a crowded room and shouted "happy birthday" at you, then you no longer count as having faith that she is throwing you a birthday party. ${ }^{6}$

The crucial condition for our purposes - and the one that Buchak spends the most time defending - is the one that relates faith with the search for evidence. The idea is that the faithful person is disposed to perform acts that are premissed upon the truth of $p$ and which express her faith that $p$, and she is disposed to do so without first seeking any evidence concerning whether $p$ beyond what she already happens to have.7 One's faith that God exists, for example, entails being disposed to perform such actions as attending worship services and giving charitably, without first seeking evidence about whether God exists, beyond what one has already $\left.\right|^{8}$ That is, the faith commitment "requires a decision to stop searching for additional evidence and to perform the act one would perform on the supposition that" $p$ is true Buchak, 2012, 234. Buchak says that "engaging in an inquiry itself constitutes a lack of faith" [ibid., 233]. Moreover, the moratorium on evidence-seeking is not just limited to full-blown inquiries concerning whether $p$ is true. Rather, the faithful person, if she can avoid it, even declines to "consider" any evidence that she happens to stumble upon [ibid.].

This does not mean, however, that the faithful person cannot seek evidence at all. She may do so for other purposes, such as to convince another person of the faith proposition, as long as she herself remains disposed to act on that proposition "regardless of what the evidence reveals" Buchak, 2012, 237.

I'll summarize this fifth condition as follows:

No-Seeking Condition: You have faith that $p$ only if you decline to seek or even consider evidence concerning whether $p$, when doing so would be for the sake of deciding whether to act on the basis of $p$ 's truth.

What if the evidence comes uninvited, so that you do not have the choice whether to consider it, and it does sway you against acting as if $p$ is true? For example, what if a third party expresses an uninvited condemnation of your friend's discretion, so that you opt against telling her your secret? I take it that this amounts to losing your disposition to tell your

\footnotetext{
${ }^{5}$ See Audi, 2011 (59-60) for an endorsement of the second and third conditions.

${ }^{6}$ This condition is controversial, but Buchak offers little argument for it. For views that deny that faith entails uncertainty, see Audi, 2011, 60-61, and Plantinga, 2000. For views endorsing Buchak's fourth condition see Swinburne, 2005.

${ }^{7}$ She surely must have at least some evidence if her faith is to qualify as rational, but our present concerns are limited to a descriptive definition of faith.

${ }^{8}$ Buchak's account is innovative in that it strikes a balance between evidentialist accounts of faith, which say that faith is typically or even normatively coupled with evidence-proportioned belief in the faith proposition (e.g. Dougherty, 2014, Plantinga, 2000, Locke, 1690/1997], Aquinas, 1485/1974), and accounts according to which faith typically or even normatively involves going beyond one's evidence in some way (e.g. James, 1921], McKim, 2001, Kierkegaard, 1941/1846], and Bishop, 2007]). On Buchak's account you can have as much evidence as you please, just as long as you commit to not seeking any more.
} 
friend your secret. $9^{9}$ and thus losing your faith. (If you had committed to acting on the faith proposition, you would be reneging on your commitment.) But what about if, after receiving uninvited evidence that speaks against $p$, you merely cease to believe that $p$ ? I take it that, as long as you are still disposed (or committed) to acting as if $p$ is true, you count as keeping your faith 10 I think that this is how how we may read Buchak's statement that faith that $p$ "does not require that one in general ignore future evidence in the matter of" whether $p$ Buchak, 2014, 56.

Buchak is careful to leave her account open to a number of conceptions of evidence. My argument will not depend on any particular conception either, but for the sake of generating a concrete counterexample below, I will construe evidence as a person's beliefs and representational experiences; as Conee and Feldman, 2004 put it, whatever a person has to go on (cf. Dougherty, 2014). Together with the No-Seeking Claim, this construal of evidence yields the result that you wind up lacking faith that $p$ if you seek to form beliefs or gain experiences that will factor into your deliberations about whether to act on the truth of $p$.

Buchak motivates the No-Seeking Condition by appeal to thought experiments. Concerning the requirement that the faithful person not conduct an inquiry into the truth concerning whether $p$, she argues as follows (Buchak, 2012, 234):

If a man has faith that his spouse isn't cheating, this seems to rule out his hiring a private investigator, opening her mail, or even striking up a conversation with her boss to check that she really was working late last night - that is, it rules out conducting an inquiry to verify that his spouse isn't cheating. If he does any of these things, then she can rightfully complain that he didn't have faith in her, even if she realizes that, given his evidence, he should not assign degree of belief 1 to her constancy. Similarly, if I have faith that my friend will keep a secret, this seems to rule out asking a third party whether he thinks that friend is trustworthy. To use a religious example, when so-called 'doubting' Thomas asks to put his hand in Jesus' side to verify that he has been resurrected in the flesh, this is supposed to indicate that he lacks faith.

Concerning the stricter requirement that the faithful person even declines to consider evidence that she happens upon by accident (unless she has inadvertently seen it already), Buchak says $[i b i d$.$] :$

[C]onsider a case in which a man simply stumbles across an envelope which he knows contains evidence that will either vindicate his wife's constancy or suggest that she has been cheating. He seems to display a lack of faith in her constancy if he opens it and to display faith in her constancy if he does not. And this seems true even if the evidence has been acquired in a scrupulous way: we might imagine the wife herself presents the envelope to the man, as a test of his faith.

These are intuitively powerful examples, and I will not question Buchak's evaluation of them. What I am contesting is that all cases of faith meet the No-Seeking Condition. I will

\footnotetext{
${ }^{9} \mathrm{I}$ think that this is the best reading of Buchak. But spelling out this scenario would require her to to say more about the conditions under which dispositions are lost, as opposed to simply not manifested.

${ }^{10} \mathrm{cf}$. Swinburne, 2005 for another account on which faith is compatible with disbelief.
} 
argue that this condition is not necessary for faith. More than this, I argue that seeking evidence for the sake of determining whether to act on the truth of a faith-proposition can in fact be an act in which faith is expressed (section 3) - and that this faith can even be highly praiseworthy (section 4).

\section{Expressing Faith by Seeking Evidence}

My argument against the No-Seeking Condition draws on an elaboration of the story of Job. Job is traditionally regarded as a paragon of faith, yet he famously demands an explanation from God for the extreme and undeserved suffering that God has allowed to befall him. Indeed, Job demands this on pain of calling God's justice and goodness into question. In addition to being an outpouring of his grief and anger, this demand has the look of a search for additional evidence about these features of God's.

Whether this is so in the story is controversial - the book of Job is notoriously difficult to interpret. My argument will not be premissed upon the claim that my reading is correct. Rather, I aim merely to use this reading as the basis for a counterexample to the NoSeeking Condition. I say "basis" because, even beyond adopting this interpretation, I will have to add certain philosophically relevant details not explicit in the text. To the extent that the resulting counterexample is a plausible rendering of the book of Job, it will enjoy the additional support of religious tradition. But all that my argument needs is for the example to be a plausible case of faith.

In this context I will assume that Job's demand for an explanation constitutes a search for additional evidence about the proposition that God is just and good. Moreover, I will elaborate on the story in such a way that the results of this search would influence Job's deliberations about whether to continue performing acts of worship.

To spell out the counterexample, we need to set the stage concerning Job's situation and what he is thinking and feeling in the midst of it.

\section{$3.1 \quad J o b ' s$ Inner State}

Job has always been an upstanding man in his community. He is so God-fearing, and loves his ten children so much, that he performs large-scale religious sacrifices on the mere off-chance that they have sinned. He is fantastically wealthy, gives copiously to the poor, and is highly respected in his community.

One day Job is visited by what Stump, 2012 describes as two "waves" of suffering (181), which are all the more intense because of their freakish nature that - on Job's worldview - can only be explained by acts of God, the very God in whom he has such faith. In the first wave, Job loses all of his possessions (including his livestock, property, and crops), and then all of his children. In the second wave, he is inflicted with a skin disease that generates loathsome and painful boils. These two waves cause still further suffering: Job is rejected by everyone in his society as cursed by God, he is plagued by night terrors, and he is brokenhearted that the God of his lifelong devotion has to all appearances not only betrayed him but is actively persecuting him. In spite of this, immediately after the first wave of suffering, 
Job bows down to worship God, and after the second, he chides his wife for urging him to curse God.

A seven-day period of silent mourning ensues, during which several companions join Job. Let us consider Job's inner state toward the end of this period, before he starts to speak with them. Job is forsaken, "aching" for his lost children [Stump, 2012], desolate, and physically and psychologically tormented - it is easy to imagine that he does not know how much more his faith can take. There are many motivations for him to demand an explanation of God, foremost among them his feeling of betrayal. But one motivation, we can easily imagine, is to determine whether to continue to perform acts of worship. If God is not just and good after all, then it would seem that worshiping him would not be morally appropriate (to say nothing of being something that Job would desire).

Let us spell out Job's motivational profile more precisely as I am envisioning it. First, we may suppose that his degree of belief that God is just and good has taken a hit because of the obliterating counterevidence of the suffering that God has allowed to befall him, an innocent and righteous man. We may suppose further that the alternative for Job would not be belief that God does not exist, but rather that a less than just and good God exists.

The latter supposition runs against the contemporary philosophical view that the only alternative to the proposition that God is just and good is that there is no God - for we tend to take justice and goodness to belong to the very concept of God ${ }^{11}$ But I think that Job's anger at God makes more sense if he does not build justice and goodness into the very concept of the being whom he is addressing, but can entertain the possibility that that being has done something unjust and evil. So what is at stake for Job is the proposition that God is just and good, as opposed to the proposition that he (exists but) isn't.

Second, Job has a number of desires. One is the desire to continue worshiping God indeed not just to perform the physical acts of worship but to perform them "from the heart." Job's loyalty to God leaves ample room for worship in the face of strong counterevidence (which, as we have seen, he performs after his first wave of suffering). However, Job does not desire to worship under just any circumstances. On the elaboration of the story I am considering, he will not worship a God who to the best of his knowledge is not just and good. For Job is also a man of integrity. We see this in the dialogues, where he shows himself unafraid, even with the grimmest of circumstances bearing down on him, to stand up for what is right - both to his friends and to God. And what is right is to get to the bottom of the apparent contradiction between the evidence of his senses and what he has heretofore believed of God. That is, Job's integrity is both moral and epistemic: his actions must be in keeping with the moral properties in the world, and achieving this requires true beliefs about those properties, where the best way available to Job of forming true beliefs is to seek and consider evidence. In order to serve this function, the evidence must not be biased, but rather as representative as he can reasonably make it.

Thus Job's loyalty and integrity seem to conflict. In order to do justice to both of these features of Job's character, I suggest that we construe his desire to worship as conditional: that is, as the desire to worship unless he rationally believes that God is not just and good. Because of his loyalty, his desire to keep worshiping extends very far beyond his evidence:

\footnotetext{
${ }^{11}$ For an alternative conception of God that would permit a softening of the traditional divine characteristics, see Wettstein, 2012.
} 
he is prepared to go a long way toward giving God the benefit of the doubt. But because of his integrity, his desire to worship stops at the threshold of belief that God is not just and good. It is this conditional desire that I will have in mind when discussing Job's desire to worship.

Yet Job has other desires that compete with his desire to worship. For example, he desires to avoid the torturous feeling of rejection that he experiences whenever he does worship; he also, due to his feeling of betrayal by God, desires to turn his back on God entirely; and so forth. These additional desires, together with his desire to worship, compete to influence Job's action - in particular, for our purposes, to influence whether he is disposed to perform acts, such as worshiping, that express faith that God is just and good. Because of Job's great faith, his desire to worship is strong; but because of his suffering, so are the competing desires.

Third, not all of his desires are of equal standing: Job identifies with some more than others. In particular, because of his faith he identifies with his desire to worship, and not with his other desires. Another way to express this identification with his desire to worship is by saying that Job has a second-order desire that his (first-order) desire to worship win out in determining his actions.

Fourth, there are a number of other psychological influences that affect whether Job will choose to perform further acts of worship. As we have seen, he is suffering physical and psychological torment. He is weary, even wishing that he had never been born. These psychological forces, understandably, are bearing down on his belief in God's justice and goodness (which, recall, has already taken a hit from the evidence of his undeserved suffering). They are also putting strong pressure on his desire to worship, and on his (second-order) identification with this desire. Finally, these other psychological influences are threatening to weaken his willpower to perform the actions that express the desires with which he most identifies.

So Job's faith is under enormous strain. We can imagine that seeking evidence is a great temptation. In particular, he will be tempted to seek evidence to shore up his belief that God is just and good, so that he can motivate himself to keep worshiping God. But - as we have seen - Job will not worship God under just any circumstances: he will only do so if he does not rationally believe that God is not just and good. Nor will his integrity permit him to seek biased evidence supporting God's justice and goodness. For these reasons, Job cannot simply search for evidence for the sake of realizing his desire to worship. If he searches, his search must genuinely be open to the possibility of discovering evidence that will - in spite of his great dismay at coming rationally to believe that God is not just and good - turn him off from worshiping entirely. That is, if Job searches for evidence, he must do so realizing that it will factor into his future decision about whether to worship. He fervently hopes that that he continues worshiping, of course, but cannot commit to doing so no matter what he discovers.

The question we are interested in is this: If Job does decide to seek additional evidence pertaining to God's justice and goodness, for the sake of influencing his decision to perform further acts of worship, does he thereby count as losing his faith that God is just and good? The No-Seeking Condition says that he does, but I will argue that he does not. To do this, I must look more closely at the effects that Job anticipates a search for evidence having on his decision whether to continue worshiping. 


\subsection{The Effect of Evidence on Job's Deliberation}

As Job sees things (we may imagine), the effect that evidence-gathering will have on his decision about whether to worship depends on what sort of evidence he winds up uncovering.

Suppose that he uncovers evidence speaking in favor of God's justice and goodness, and that he uncovers no additional evidence against God's having these properties. To the extent that this evidence is strong, and that it outweighs or makes sense of his recent experiences, Job thinks that it will remove some of the pressure on his belief that God is just and good, on his desire to worship, on his identification with that desire, and on his willpower. In short, it will be an encouragement for his faith. So Job's discovering positive evidence will, he reasons, make him more likely to decide to perform further acts of worship.

What if, by contrast, Job discovers additional evidence that speaks against God's justice and goodness, and receives no positive evidence to balance it out? As he envisions matters, there are two sub-cases. In one, this counterevidence pushes him to rationally believe this. Job is aware that his desire to worship is conditional on his not believing that God is not just and good. He also realizes that there is already great pressure on his desire to worship even when he still (barely) believes that God is just and good. So it is clear to him that, should the counterevidence make him believe that God is not just and good, he will stop worshiping God. In this scenario he will therefore lose his faith entirely.

In the second sub-case that Job considers, he receives additional evidence against God's justice and goodness, but not enough to make him believe that God is not just and good. So this evidence will not automatically persuade him to stop worshiping God. What he thinks it may do, however, is make worshiping even harder than it already is. More counterevidence will further batter his already beleaguered degree of belief, with the knock-on psychological discouragement that we would expect: his desire to worship will be weakened and his contrary desires strengthened, his identification with his desire to worship will be weakened, as will his will to act on that desire. In short, Job anticipates that receiving negative evidence will greatly lower the probability that he decides to continue performing acts of worship, and may even destroy his faith.

In summary, these are the three possible outcomes, as Job sees it, of seeking additional evidence: he receives positive evidence, he receives negative evidence that makes him rationally believe that God is not just and good, or he receives negative evidence that does not (quite) make him believe this ${ }^{12}$ At the place where we have left him in the story, Job stands before the decision to search for additional evidence for the sake of deciding whether to keep worshiping. The No-Seeking Condition says that, if he does search for additional evidence, he will thereby count as losing his faith that God is just and good. Will he?

In order to answer this question, Job must consider one more outcome: the one in which he declines to search for evidence at all. How likely does he take himself to be to decide in this case, after he has lost everything and sat in the dust for seven days scratching his boils, to continue worshiping? There are many factors working against his assigning a high probability to his choosing to continue worshiping. As we have already seen, he (still) desires to worship and (still) identifies with this desire. Yet there is also tremendous pressure, from every other aspect of his motivational structure, against willing this desire into action, indeed against

\footnotetext{
${ }^{12}$ I will ignore cases in which Job's evidential state does not change in spite of his search or delivers some mixed result.
} 
maintaining this desire - to say nothing of identifying with it - to begin with. This includes evidential pressure on his degree of belief, which is not as great as in the scenario where Job receives additional negative evidence, but is still great nonetheless. And there is another source of pressure in this scenario that is not present in the ones in which Job seeks evidence: the frustration at doing nothing, which disposes his faith-friendly desires to putrefy. These combined pressures may prove too much. It turns out, then, that not searching for evidence might result in his deciding not to perform further acts of worship, and might even destroy his faith too. Indeed, he sadly assigns this outcome a significant probability, though perhaps less than were he to uncover additional negative evidence.

Declining to seek evidence could of course turn out otherwise: he might manage in spite of everything to decide to keep worshiping or at least to cling to his faith by expressing it with less demanding actions. Yet the more desolate Job becomes, the less likely he takes this outcome to be. Moreover, even if he does keep his faith on this scenario, this faith will continue to be painful and conflicted. It will continue to be subject to pressure, unless - in spite of himself - Job happens unwillingly to stumble upon positive evidence that he did not seek.

\subsection{The Effect of Evidence-Seeking on Job's Faith}

So, would Job lose his faith by seeking evidence in order to determine whether to perform future acts of worship? I claim that he would not. Why not? Because he still identifies with his desire to worship. And he believes, indeed reasonably, that in this impossible situation the best thing he can do to honor this second-order desire is to search for evidence to influence his future decision. He knows that he risks receiving evidence that will discourage him even further from worshiping, but he hopes against hope that this will not happen. And the best outcome on the branch in which he seeks evidence is far better than either outcome on the branch on which he declines to do so - for on the latter his faith either withers or remains tortuously conflicted 13

In other words: In the situation as described, Job's searching for evidence in order to decide whether to keep worshiping is itself an action that expresses his faith. Far from thereby losing his faith, Job manifests its sheer extent. ${ }^{14}$

One might think that this result is limited to situations in which Job believes it fairly likely that he will receive positive evidence. That is, one might think that evidence-seeking can only be an expression of Job's faith to the extent that he believes that he will receive evidence favoring God's justice and goodness - otherwise, one might think, he can only express his faith by sitting tight with his current evidential situation. And the objector might add that Job is unlikely to believe this, given that his degree of belief has already been battered by counterevidence and psychological factors. So even if I have located a counterexample to the No-Seeking Condition, one might object that there is only a very narrow sphere in which structurally similar cases will arise.

\footnotetext{
${ }^{13}$ Given these considerations, seeking evidence is arguably also the rational thing for Job to do to realize his second-order desire.

${ }^{14}$ cf. Audi, 2011: "Believing on faith ... is compatible with seeking evidence - and with having faith that it will be found" (59).
} 
In response, the objector is mistaken in claiming that evidence-seeking is only likely to be compatible with faith should Job's expectation of positive evidence be fairly high. On the contrary, it is compatible with faith even should this expectation be very low. For there are other factors than his current credence in God's justice and goodness which affect Job's decision to seek evidence, and it is the presence of some of these factors that produce his great faith. One is the value that Job ascribes to the outcome in which he receives positive evidence. If this outcome is for him of supreme value (and it is), then he may be willing to risk much for even the slimmest hope of achieving it. Another factor is Job's strong disvalue of the scenario in which, precisely because he has not sought any evidence, he watches helplessly as his faith withers into nothing; once more, we seem to be dealing with profound faith. As long as there is even the slightest hope of positive evidence, the risk of negative evidence is worth it to Job.

More than this, Job's evidence-search is an expression of faith even when Job has a very high expectation of uncovering evidence against God's justice and goodness. This might come as a surprise: for on this terrible outcome, Job would likely lose his faith. But nonetheless, his embarking on a search for evidence, even with a high expectation of losing his faith, is compatible with his having great faith at the time of his embarking, and with this embarking being an expression of his faith. To see this, consider that Job has already done all that he can, short of evidence-seeking, to motivate God to save his faith - yet his worship, tears, and prayer have had no effect. Searching for evidence even with a high expectation of losing his faith as a result is the last thing that it is in his power to do. Job's faith is his most cherished remaining possession - but he sees risking it as the last chance he has of saving it for the longer term. He hopes against hope that, since nothing else has motivated God to prop up Job's faith, Job's putting that very faith on the line might finally move God. It is an action premissed - if desperately - upon God's being just and good. This is Job's way of saying, "If you are just and good, and if my faith is of any value to you, then it is yours to save, for doing so may soon be beyond my power."

But the proponent of the No-Seeking Condition might object. She may claim that Job is not motivated to search for evidence for the sake of deliberating about whether to continue worshiping; rather, he is motivated for the sake of saving his faith if at all possible. In other words, Job's search for evidence will not be for the sake of figuring out what decision to make, but rather for the sake of empowering him, if the gamble pays off, to make the decision that he wants to make already. Hence Job is not motivated to search for evidence for the sake of deliberating about whether to continue worshiping, or of performing any act that would express faith. Job therefore does not violate the No-Seeking Condition.

This objection would have some traction if the desire with which Job identified were to worship God no matter what. In this case, any deliberations on the truth of the matter - on whether God possesses the worship-worthy characteristics of justice and goodness - would merely be a means toward worshiping, so that if another means proved more promising, he would employ this instead. If for instance he could swallow a pill that would override his deliberations, then he would jump at the chance. It's just that he unfortunately has no such pill, and judges that rational deliberation, together with the a-rational influences that the hoped-for positive evidence might provide, is the best way forward of a bad lot. If this were an accurate characterization of Job's desire, then Job's evidence-seeking would not, in this case, be for the sake of figuring out whether to worship, but rather for the sake of worshiping. 
But this description does not accurately capture Job's desire. His desire is not to worship God no matter what, but to worship God unless he rationally believes that God is not just and good. Recall that Job is a man not only of loyalty but of integrity, and that his integrity cannot stand the prospect of worshiping a God who is not just and good. (One might suspect that Job's integrity places a limitation on the extent of his faith that God is good and just, so that Job's faith cannot be his most treasured possession after all. But in the next section I will argue that his integrity is itself a praiseworthy aspect of Job's faith.) Because this is his desire, Job's evidence-seeking does concern the decision whether to worship.

It is true that Job hopes that he will wind up deciding to worship, but this in itself does not establish that he is not motivated to deliberate about what is true. Note that people regularly hope that their searches for evidence will yield particular outcomes. For example, when I look at the weather report I hope that my evidence will influence me to leave my umbrella at home tomorrow; this is because I hope it doesn't rain, not because I want to leave my umbrella behind even if it does rain. A similar remark applies to Job. He hopes that his evidence will influence him to worship, but this is because he hopes that his evidence will indicate that God is just and good. He doesn't want to worship God if his evidence compels belief that this is not the case.

In summary, because Job has integrity as well as loyalty, he is motivated to search for evidence for the sake of deliberating about whether to worship. He thus violates the NoSeeking Condition. Yet I have argued that, should he search for evidence about whether God is just and good, this search will be an expression, rather than a loss, of his faith that God is just and good.

\section{Is Declining to Seek Evidence Praiseworthy?}

I have argued that Job's evidence-seeking is an expression of faith because it shows what God - should he truly be just and good - is worth to Job. It is a risk that Job takes in faith. One might still object, however, that Job's faith would be more praiseworthy were he able to sustain it without additional evidence. The objector will grant that one cannot blame Job for seeking evidence, for he has been pushed to his limits and his evidence-seeking is after all an expression of his faith. But there does seem to be something praiseworthy about a faith that carries on by itself, without need of psychological or rational reinforcement. The objector will propose re-figuring the No-Seeking Condition as normative, rather than necessary:

Normative No-Seeking Condition: It is praiseworthy, when you have faith that $p$, to decline to seek or consider evidence concerning whether $p$, when doing so would be for the sake of figuring out whether to act on the basis of $p$ 's truth.

But I will argue that the Normative No-Seeking Condition is false. Declining evidence for the sake of practical reasoning, when one has faith, is not as such praiseworthy. There are situations in which it might be praiseworthy, but there are equally situations in which seeking evidence is praiseworthy.

The example of Job will prove helpful here too. As above, my aim is not to appeal to the authority of the text but rather to present a particular interpretation as an example of the aspect of faith that I am pinpointing. That this example really amounts to faith will 
be argued on its merits rather than its source. And this is regardless of whether the reader agrees that my interpretation is plausible, though if and to the extent that it is, this fact will further support my argument.

\section{1 "As for You, You Whitewash with Lies"}

So let us return to Job. We will fast-forward to the middle of the dialogues. Job's companions for their part have been chiding Job for his supposed arrogance; they reason that, because God is just, Job's lot can only be deserved. As a result, they tell Job to confess his sins and repent. Job responds as follows (RSV, 13:4-12):

"As for you, you whitewash with lies....

Will you speak falsely for God,

and speak deceitfully for him?

Will you show partiality toward him, will you plead the case for God?

Will it be well with you when he searches you out?

Or can you deceive him, as one deceives a man?

He will surely rebuke you

if in secret you show partiality."

I'd like to highlight three things that Job seems to be saying here. One is that his companions, instead of looking at the facts about the dispute between Job and God, have sided with God automatically. They have simply assumed that God has nothing to answer for about Job's situation. That is, they are "show[ing] partiality", siding with God simply because he is God.

Second, Job says that his companions' defense of God and condemnation of Job are not only mistaken but deceitful. Whom are they trying to deceive? One target is surely Job, to whom they are speaking. What they want Job to believe is that he must be guilty, because after all God has let him suffer - and they regard his demanding an explanation of God as incurring further guilt. That is, they seem to want Job to believe that he is blameworthy for (among other things) seeking and considering evidence concerning God's justice and goodness.

There is a second target of their deceit, whom Job says is God himself. Let us suppose that Job is right about this. What might their motive be for deceitfully telling God that Job is guilty? It cannot be to make God believe that this is so (for if they are right, he already does believe this). To see what they might be doing, imagine a monarch who suddenly orders that the most apparently loyal courtier in her entourage be thrown into the dungeons and tortured. The remaining courtiers would be terrified. Surely many would fall all over themselves to publicly applaud the monarch's actions in the hopes that, in perceiving their apparent loyalty, she will not do the same thing to them. It seems, then, that Job is accusing his friends of disingenuously flattering God, as one might flatter such a fickle absolute monarch.

But can Job's friends really be construed as trying to deceive God? For deceit would seem to entail disbelieving what one says: if a child deceitfully says that she has not stolen a biscuit, then we can expect her to believe that she has indeed stolen a biscuit. Job's friends, 
by contrast, give every impression of believing that Job is guilty - how, then, are they being deceitful about this? The answer is that there is one kind of deceitfulness that need not involve believing the opposite of what you assert: self-deceit. On [Mele, 2001]'s influential account of self-deception, you can self-deceptively believe that $p$ simply by "positively misinterpreting" evidence concerning whether $p$. This happens when you strongly desire that $p$ be true, yet your evidence would be "easily recognize[d] to count against $p$ in the desire's absence" Mele, 2001, 26.15 This is what I am suggesting that Job is accusing his friends of. Although they arguably do believe that Job is guilty, they can only believe this in utter defiance of the evidence of their senses. It is this evidence that they have "whitewashed": evidence that the righteous suffer. Job, then, seems to be saying something like, "All of your evidence indicates that what you are saying is absurd. Why won't you recognize this?" The answer is that believing that Job is innocent would come at too great a cost - to the coherence of their worldview, and to their own sense of safety as righteous men in a divinely ordered world. So their deception of God and Job may not be the straightforward telling of an acknowledged untruth, but it is at least an extension of their own culpable self-deception.

The third thing that Job says which I'd like to highlight is that God disapproves of the companions' partiality toward him. God will rebuke them, Job says - which he indeed does at the end of the story (42:7): "My wrath is kindled against you [Eliphaz] and against your two friends, for you have not spoken of me what is right, as my servant Job has". Why would God be angry? Consider how a monarch who truly is just and good - rather than vain and fickle - would react to self-interested, deceitful and self-deceitful flattery. She would be furious: her courtiers would be treating her as if her favor were for sale. All the more so with God. God, Job warns, sees through his friends' deceit, and will be indignant at the attribution of corruptibility with which it implicitly smears him.

What has Job done, by contrast, to elicit God's approval, to the point that God verbally takes him under his wing as his "servant"? I take the answer to be that Job has not played the sycophantic courtier. On the contrary, he has continually treated God as if God is answerable to the highest moral standards. Whereas his friends, out of concern for their position, are prepared to turn a blind eye to possible violations of these standards on God's part, Job is unafraid to speak truth to power, even after experiencing the terrible force of that power 16 A truly just and good monarch would know the value of such a servant. Job has God's priorities, justice and goodness, at heart, and will offer his services, at possible cost to himself, to promote them - even if this means calling into question the justice and goodness of God's own actions 17

What God is approving of, then, is precisely Job's faith - and the fact that considering and seeking evidence are among the ways in which Job expresses it. If we recall my characterization of Job's faith (section 3.1), we can see more closely why this might be so. I

\footnotetext{
${ }^{15}$ There are probably other forms of self-deception (for discussion see [Davidson, 1986, Haight, 1980], Pears 1985]); but Mele, 2001]'s account certainly describes a real phenomenon, and it coheres the best with the interpretation of the passage I am working with.

${ }^{16}$ It is tempting to spell out the difference between Job and his friends in terms of Job taking one side of the Euthyphro dilemma and his friends the other, but I won't explore this possibility here.

${ }^{17}$ As Wettstein, 2012 notes, "what is most salient about [the comforters'] speeches, what they insisted upon, and what Job denied, was the just reality behind the unjust appearances....Unwarranted suffering is no mere surface appearance, but a ground floor phenomenon, not to be explained away" (151-152).
} 
claimed that Job's faith is marked by two characteristics: loyalty and integrity. Job's loyalty, I said, disposes him to worship God even in the face of evidence against God's justice and goodness, while his integrity keeps him from being disposed to worship should he come rationally to believe that God is not just and good. And I said that integrity has a moral and an epistemic dimension. The person with integrity strives to ensure that her actions are in keeping with the moral properties in the world; and she strives to achieve this by engaging responsibly with evidence concerning those properties. That is, she considers the evidence that she has, seeks additional evidence where needed, does her best to ensure that her evidence is representative rather than biased, and (unlike Job's companions) she tries to prevent non-epistemic motives from unreasonably distorting her interpretation of it.

We may express the matter like this. Job, unlike his friends, is aware that a just and good God will have the following counterfactual desire: "If I were not just and good, you would not worship me". A just and good God has this desire because worshiping a being that does not deserve it does violence to the truth: it would express an attitude - worshipfulness that is grotesquely inappropriate to its object. And it would do violence to what is right, because worshiping an undeserving object, at least in the universe of Job, is morally wrong - indeed, it is idolatrous. Striving to realize this counterfactual desire of God's, then, is one way to act on the truth of the proposition that God is just and good, and doing so requires solid information about God's actual justice and goodness.

We may contrast Job's faith to his companions'. Their faith includes loyalty to God, but it lacks integrity. It lacks moral integrity in that the companions are more concerned with flattering God for their own gain than worshiping him "from the heart". It lacks epistemic integrity in that they are ready to believe, come what may, that God is just and good, even against the evidence of their senses. Because the companions' loyalty is unchecked by moral or epistemic integrity, it degrades into sycophancy. Job, by contrast, preserves the caliber of his loyalty by matching it with integrity. In this Job, unlike his friends, is God's servant - even though, and indeed because, he calls into question the justice and goodness of God which his friends unthinkingly proclaim.

In other words, it is by seriously considering counterevidence with the intention of determining his future actions that Job has won God's favor. The reason is not only that doing so is a last-ditch means for Job to try to cleave to God, but also because of the intrinsic role that the consideration of evidence has in promoting the truth. It would appear that Job's seeking of evidence is not just the second-best expression of a faith that would be more praiseworthy without it, but that on the contrary it makes Job's faith more praiseworthy than it would otherwise have been - and indeed more praiseworthy than that of his companions, who seek to respect both varieties of the No-Seeking Condition.

\subsection{Discussion}

So what is the relationship of evidence-seeking to faith? Not only is it not as fraught as it is sometimes taken to be, but there are situations in which evidence-seeking sits very well with faith, indeed is a praiseworthy expression of it.

Is there nothing to be said for the strong intuitions underlying the cases with which Buchak argues for the No-Seeking Condition? Recall the husband whose wife rightfully accuses him of unfaithfulness for opening an envelope with information about her fidelity. 
Recall Doubting Thomas, whom Jesus accuses of a lack of faith when he refuses to believe, without tactile evidence, that Jesus was raised from the dead. These are cases in which a search for evidence for the sake of acting really does seem to be not only unpraiseworthy, but incompatible with faith. Don't they indicate that something must be amiss with my account? They do not. I am not arguing that evidence-seeking never makes faith less praiseworthy; and what I have said is compatible with the claim that it sometimes does destroy faith. Indeed, it is plausible that declining to seek evidence can also, in the right circumstances, be an expression of faith - just as seeking it can be.

The key, I take it, is in distinguishing the variables that make each the case. I suggest that one variable is the proportion of evidence that you have for vs. against your faith proposition, and that another is the way in which your total evidence affects your motivational profile. A third variable pertains to aspects of your relationship with the person featuring in your faith proposition, including your response to things that she values ${ }^{18}$

Suppose for example that the husband in Buchak's case has no reason but his own insecurities to call his wife's constancy into question, against the backdrop of years of emotional intimacy that have yielded strong evidence of her honesty and devotion. Here, Buchak's assessment that opening the envelope constitutes a lack of faith seems justified.

But suppose that he has received some not insignificant circumstantial evidence against his wife's constancy, and noticed independently that her character or priorities might be changing and that she is less emotionally open with him than she used to be. Suppose also that, as he ages, some deep insecurities about his own desirability, unresolved from long ago, are intruding on his motivational structure. In this case it could be that opening the envelope, while not incompatible with his faith, is still far from praiseworthy. (Perhaps a more mature way to address his concerns would be to gingerly raise the prospect of couple counseling.)

Finally, we might add background information to make the case resemble that of Job and God, so that the husband has received - unbidden - strong enough counterevidence to severely shake his belief in his wife's constancy, and to batter his desires to act on this belief. Moreover, his wife wrote him a letter when they first married, proclaiming her desire that honesty and truth be the lodestar of their marriage; and the husband is confident that, whatever else might be going on with his wife, she still stands by this on some level. In the present situation, given the shocking counterevidence, he judges that opening the letter would not only be the best move for psychologically saving his faith, but also for honoring the person he married all those years ago. If we spell out this case along these lines, then the husband's opening the envelope could be construed not as a renunciation of his faith, nor even as a normative mark against it, but rather as a praiseworthy expression of it.

There are surely other variables affecting how a given instance of evidence-seeking for the sake of practical reasoning affects the faith of the person engaging in it. Three, in any case, seem to be the proportion of positive to negative evidence, the person's motivational profile, and features of her relationship with the other party.

\footnotetext{
18 Audi, 2011]'s comment about faith in persons is applicable: "[F]aith in a person usually implies the appropriateness, and sometimes a prima facie obligation to maintain, [...] faithfulness to the standards or values - such as justice and honesty - with respect to which one has faith in the other" (297).
} 


\section{Conclusion}

The relationship of faith to the seeking (or considering) of evidence for the sake of practical reasoning is complex. Although it is tempting to think that evidence-seeking is incompatible with faith, I have argued that they are compatible - and moreover that evidence-seeking can be an expression of faith. But it is also tempting to think that, even in situations where this is so, evidence-seeking makes for at least a less praiseworthy faith. I have argued that this is also not the case: evidence-seeking can make for a faith that is more praiseworthy than otherwise. There are many variables that influence the evaluation of cases in which a faithful person seeks or declines to seek evidence for the sake of practical reasoning. Three are, roughly: the total evidence of the putatively faithful (or faithless) person, that person's motivational profile, and features of the relationship that she has with the person whose actions or characteristics the faith proposition pertains to. I leave a more detailed discussion of these variables to future research.

\section{References}

[Aquinas, 1485/1974] Aquinas, Thomas (1485/1974), ed. T. C. O'Brien. Faith: St. Thomas Aquinas's Summa Theologiae, Vol. 31 (2a2ae. 1-7), London and New York: Blackfriars.

[Audi, 2011] Audi, Robert (2011). "Faith, Faithfulness, and Virtue", Faith and Philosophy, 28, 3, 294-309.

[Audi, 2011] Audi, Robert (2011). Rationality and Religious Commitment, Oxford: Oxford University Press.

[Bishop, 2007] Bishop, John (2007). Believing by Faith: An Essay in the Epistemology and Ethics of Religious Belief, Oxford: Oxford: Oxford University Press.

[Buchak, 2012] Buchak, Lara (2012). Probability in the Philosophy of Religion, eds. Jake Chandler and Victoria Harrison, Oxford: Oxford University Press.

[Buchak, 2014] Buchak, Lara (2014). Religious Faith and Intellectual Virtue, eds. Laura Frances Callahan and Timothy O'Connor, Oxford: Oxford University Press.

[Conee and Feldman, 2004] Conee, Earl; Richard Feldman (2004). Evidentialism, Oxford: Oxford University Press.

[Davidson, 1986] Davidson, Donald (1986). "Deception and Division", The Multiple Self, ed. John Elster, Cambridge: Cambridge University Press.

[Dougherty, 2014] Dougherty, Trent (2014). "Faith, Trust, and Testimony: An Evidentialist Account", Religious Faith and Intellectual Virtue, Laura Frances Callahan and Timothy O'Connor, eds., Oxford: Oxford University Press, 98-124.

[Haight, 1980] Haight, Mary (1980). A Study of Self-Deception, Sussex: The Harvester Press. 
[James, 1921] James, William (1921). The Will to Believe, Human Immortality, and Other Essays in Popular Philosophy, an Human Immortality, Longmans, Green, and Co.

[Kierkegaard, 1941/1846] Kierkegaard, Soren (1941/1846). Concluding Unscientific Postscript, trans. D. F. Swenson, Princeton: Princeton University Press.

[Locke, 1690/1997] Locke, John (1690/1997). An Essay Concerning Human Understanding, Roger Woolhouse, ed., London: Penguin.

[McKim, 2001] McKim, Robert (2001). Religious Ambiguity and Religious Diversity, Oxford: Oxford University Press.

[Mele, 2001] Mele, Alfred (2001). Self-Deception Unmasked, Princeton: Princeton University Press.

[Pears 1985] Pears, David (1985). "The Goals and Strategies of Self-Deception", The Multiple Self, ed. Jon Elster, Cambridge: Cambridge University Press.

[Plantinga, 2000] Plantinga, Alvin (2000a). Warranted Christian Belief, Oxford: Oxford University Press.

[Stump, 2012] Stump, Eleonore (2012). Wandering in Darkness, Oxford: Oxford University Press.

[Swinburne, 2005] Swinburne, Richard (2005). Faith and Reason, 2nd Ed. Oxford: Oxford University Press.

[Wettstein, 2012] Wettstein, Howard (2012). The Significance of Religious Experience, Oxford: Oxford University Press. 